\title{
Development and Validation of UV Spectrophotometry and Liquid Chromatography Methods for Determination of Cefpirome in Raw Material and Pharmaceutical Dosage
}

\author{
Tércio Paschke Oppe* ${ }^{\mathrm{a}}$, Júlia Menegola $^{\mathrm{a}}$, Elfrides Eva Scherman Schapoval ${ }^{\mathrm{a}}$ \\ Faculdade de Farmácia, Universidade Federal do Rio Grande do Sul, Avenida Ipiranga 2752, CEP: 90610-000, Porto Alegre, RS \\ - Brasil. \\ *Corresponding author: tercio.oppe@ufrgs.br
}

In the present work, analytical methods, UV Spectrophotometry and Liquid Chromatography (HPLC), were developed and validated for quantification of cefpirome, a broad-spectrum fourth-generation cephalosporin, in raw material and powder for injectable preparation. The UV spectrophotometric method was performed at $271 \mathrm{~nm}$, using $0.1 \mathrm{M}$ hydrochloric acid as solvent. The HPLC was carried out using Techsphere ODS column and mobile phase consisted of methanol-water (30:70, v/v) with flow rate $0.8 \mathrm{~mL} / \mathrm{min}$ and $\mathrm{UV}$ detection at $265 \mathrm{~nm}$. The validation method yielded good results demonstrated statistically that the methods were linear, precise, accurate, specific and robust. A preliminary stability study of cefpirome showed that the UV Spectrophotometry and Liquid Chromatography methods were specific for the determination cefpirome in the presence of its degradation products. No statistically difference was observed between the proposed methods. The UV Spectrophotometry and Liquid Chromatography methods allow the quantitation of cefpirome in pharmaceutical dosage form and raw material and can be used for the drug analysis in routine quality control.

Keywords: cefpirome, UV spectrophotometry, liquid chromatography, method validation, stability

\section{Introduction}

Cephalosporin is a group of broad-spectrum derived from species of fungi of the genus Cephalosporium and are related to the penicillins in both structure and mode of action but relatively penicillinase-resistant antibiotics. These antibiotics have low toxicity for the host, considering their broad antibacterial spectrum. They have the active nucleus of beta-lactam ring which results in a variety of antibacterial and pharmacologic characteristics when modified mainly by substitution at 3 and 7 positions. Their antibacterial activities result from the inhibition of mucopeptide synthesis in the cell wall. Traditionally, the cephalosporins are divided into first-, second-, third-, fourth and fifth-generation agents (1-3).

Cefpirome, [6R-[6 $\quad$, $7 \beta(Z)]]-1-[[(2-A m i n o-4-t h i a z o l y l)$ (methoxyimino)acetyl] amino]-2-carboxy-8-oxo-5-thia-1azabicyclo[4.2.0]oct-2-em-3-yl]methyl]-6,7-dihydro-5H-

cyclopenta[b]pyrindinium inner salt (3) (Figure 1), is an injectable broad-spectrum aminothiazolyl cephalosporin, produced as sulfate salt. It is considered to be highly active against both gram-negative organisms including Pseudomonas aeruginosa and gram-positive organisms including staphylococci. It is stable to both plasmid and chromosomal $\beta$ - lactamases and has been shown to induce less class I $\beta$ - lactamase resistance than other cephalosporins $(2,5-7)$.

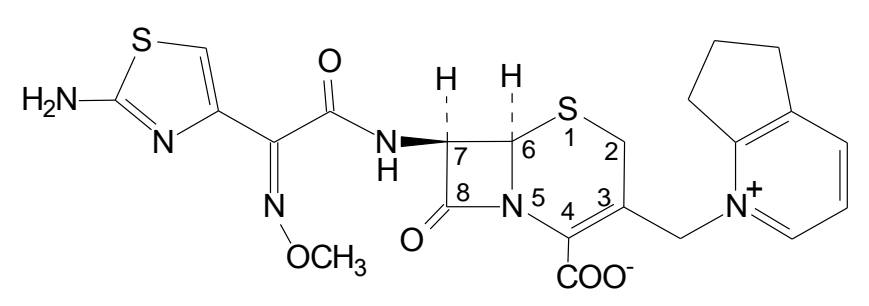

Figure 1. Chemical structure of cefpirome
The increased spectrum of activity, together with high stability against $\beta$-lactamases and rapid transmembrane transport, distinguishes cefpirome as an example of a fourthgeneration cephalosporin and its principal use is in treatment for patients' septic shock or several sepsis (2,5-10).

Methods have been reported for the determination of cefpirome in plasma, serum, urine, tissue, raw material and pharmaceutical form. These methods include microbiological assay, HPLC, voltammetry assay, UV spectrometry and $\mathrm{pH}$ potentiometry (2,7-19). The aim of this study was to develop and validate simple and rapid UV Spectrophotometry and Liquid Chromatography (HPLC) methods for the quantification of cefpirome in raw material and powder for injectable preparation. These methods were validated according to the International Conference on Harmonization (ICH) guidelines (20).

\section{Materials and Methods}

\section{Chemicals and reagents}

The cefpirome standard (assigned with content of cefpirome $823 \mathrm{mg} / \mathrm{g}$, batch $\mathrm{n}^{\circ}$. C 150.05 (SS)) was kindly supplied by Aventis Pharma (Frankfurt, Germany), pharmaceuticals dosage form (Cefrom ${ }^{\circledR}$ - injectable) containing cefpirome was obtained commercially from Aventis Pharma (São Paulo, Brazil) and it was claimed to contain $1 \mathrm{~g}$ (as anhydrous base). All reagents used were of analytical or HPLC grade, purchased from Tedia (Rio de Janeiro, Brazil), Lichrosolv (Darmstadt, Germany) and Merck (Darmstadt, Germany) and the water was ultra-purified by Filtrosul system (Porto Alegre, Brazil).

\section{UV spectrophotometric conditions}

The UV method and spectra were performed on a Schimadzu UV-visible spectrophotometer UV-1601 PC with Uvpc software (Shimadzu, Kyoto, Japan) using $1.0 \mathrm{~cm}$ 
quartz cells, optical path of $10 \mathrm{~mm}$. The spectra were recorded using $1 \mathrm{~mm}$ slit and $120 \mathrm{~nm} . \mathrm{min}-1$ scanning speed. The assay was performed at analytical wavelength $271 \mathrm{~nm}$ (with $\pm 0.5 \mathrm{~nm}$ of wavelength accuracy) and $0.1 \mathrm{M}$ hydrochloric acid $(\mathrm{HCl})$ as solvent.

\section{HPLC conditions}

The Liquid chromatography system consisted of a Schimadzu SCL-10A, with SPD-M10A Diode Array Detector (set at $265 \mathrm{~nm}$ ), a SCL-10A VP system controller, a LC 10 AD VP pump, a SIL-10AD auto injector syringe unit, a CTO-10AC VP Column Oven (set at $25^{\circ} \mathrm{C}$ ), ClassVP software (Shimadzu, Kyoto, Japan) and Techsphere ${ }^{\circledR}$ ODS RP-18 column $(5 \mu \mathrm{m}, 250 \mathrm{~mm}$ x $4.6 \mathrm{~mm}$ ) (HPLC Technology - Welwyn Garden City, United Kingdom) fed with methanol-water $(30: 70, \mathrm{v} / \mathrm{v})$ with flow rate $0.8 \mathrm{~mL} / \mathrm{min}$.

\section{Reference and samples preparation}

To UV spectrophotometry method, the reference and samples solutions were prepared using an amount of powder equivalent to $24 \mathrm{mg}$ of cefpirome that was transferred to 100 $\mathrm{mL}$ volumetric flask with $0.1 \mathrm{M}$ hydrochloric acid and followed by making up to final volume with this solvent (240 $\mu \mathrm{g} / \mathrm{mL})$. An aliquot of this solution $(5 \mathrm{~mL})$ was transferred to the $100 \mathrm{~mL}$ volumetric flask and made up to final volume with $0.1 \mathrm{M}$ hydrochloric acid $(12 \mu \mathrm{g} / \mathrm{mL})$.

To HPLC method, the reference and samples solutions were prepared using an amount of powder equivalent to $25 \mathrm{mg}$ of cefpirome that was transferred to $100 \mathrm{~mL}$ volumetric flask with ultra-purified water and followed by making up to final volume with this solvent $(250 \mu \mathrm{g} / \mathrm{mL})$. An aliquot of this solution $(4 \mathrm{~mL})$ was transferred to the $100 \mathrm{~mL}$ volumetric flask and made up to final volume with ultra-purified water $(10 \mu \mathrm{g} / \mathrm{mL})$. In each assay, $20 \mu \mathrm{L}$ of solution was used.

\section{Methods validation}

The methods were performed and validated by determination of the following operational characteristics: linearity, range, precision, accuracy, specificity, limit of detection, limit of quantitation and robustness.

\section{Linearity}

The linearity of the methods were determined using cefpirome standard at different concentrations levels. Three calibration curves were prepared by day, for three consecutives days. The slopes and the statistical analysis of the calibration curves were calculated by linear regression. To UV spectrophotometry method, after choose the best solvent and wavelength, Ringbom's curve was prepared using range concentration of cefpirome between 2.0 to 40.0 $\mu \mathrm{g} / \mathrm{mL}$, using $0.1 \mathrm{M}$ hydrochloric acid as solvent, the calibration curves were obtained after an amount of powder equivalent to $20 \mathrm{mg}$ of cefpirome has transferred to $500 \mathrm{~mL}$ volumetric flask with $0.1 \mathrm{M}$ hydrochloric acid, followed by making up to final volume with this solvent $(40 \mu \mathrm{g} / \mathrm{mL})$. Aliquots of this solution were transferred to the $20 \mathrm{~mL}$ volumetric flask and made up to final volume with $0.1 \mathrm{M}$ hydrochloric acid to obtain the concentrations of 6.0, 8.0, 12.0, $14.016 .0,18.0$ and $22.0 \mu \mathrm{g} / \mathrm{mL}$. Each solution was assayed three times.

The calibration curves, to HPLC method, were prepared using range concentration of cefpirome between 2.0 to 20 $\mu \mathrm{g} / \mathrm{mL}$. An amount of powder equivalent to $20 \mathrm{mg}$ of cefpirome has transferred to $500 \mathrm{~mL}$ volumetric flask with ultra-purified water, followed by making up to final volume with this solvent $(40 \mu \mathrm{g} / \mathrm{mL})$. Aliquots of this solution were transferred to the $20 \mathrm{~mL}$ volumetric flask and made up to final volume with ultra-purified water to obtain the concentrations of 2.0, 5.0, 7.0, 10.0, $12.015 .0,18.0$ and 20.0 $\mu \mathrm{g} / \mathrm{mL}$. Triplicate injections of each solution were made into the HPLC system.

\section{Precision}

The precision of the assay was determined by repeatability (intra-assay) and intermediate precision (inter-assay). Repeatability was evaluated by assaying three samples at the same concentration and during the same day. The intermediate precision was certificated by comparing the assays on three different days. The precision is calculated by relative standard deviation (RSD) (20-22).

\section{Accuracy}

The accuracy was determined by recovery, in which known amount of cefpirome reference substance was added to the samples at the beginning of the process. The recovery test was performed at three concentration levels. The percentage recovery of cefpirome reference added was calculated using the equation proposed by AOAC (22).

In UV spectrophotometry method, an amount of powder equivalent to $24 \mathrm{mg}$ of cefpirome (sample) was transferred to $100 \mathrm{~mL}$ volumetric flask with $0.1 \mathrm{M}$ hydrochloric acid and followed by making up to final volume with this solvent (240 $\mu \mathrm{g} / \mathrm{mL})$. An aliquot of this solution $(5 \mathrm{~mL})$ was transferred to the three $100 \mathrm{~mL}$ volumetric flask and aliquots of $5.0 \mathrm{~mL}, 10.0$ and $15.0 \mathrm{~mL}$ of a $60 \mu \mathrm{g} / \mathrm{mL}$ of cefpirome reference substance were added in each volumetric flask and made up to final volume with $0.1 \mathrm{M}$ hydrochloric acid (corresponding to 300, 600 and $900 \mu \mathrm{g}$, respectively). The solutions contending final concentrations of 15.0, 18.0 and $21.0 \mu \mathrm{g} / \mathrm{mL}$ of cefpirome were submitted to the UV spectrophotometric assay described above. Each solution was prepared in triplicate in two days.

To the HPLC method, an amount of powder equivalent to 25 $\mathrm{mg}$ of cefpirome was transferred to $100 \mathrm{~mL}$ volumetric flask with ultra-purified water and followed by making up to final volume with this solvent $(250 \mu \mathrm{g} / \mathrm{mL})$. An aliquot of this solution (4 mL) was transferred to the three $100 \mathrm{~mL}$ volumetric flasks and aliquots of $5.0 \mathrm{~mL}, 7.5$ and $10.0 \mathrm{~mL}$ of a $100 \mu \mathrm{g} / \mathrm{mL}$ of cefpirome reference substance were added in each volumetric flask and made up to final volume with ultra-purified water (corresponding to $0.5,0.75$ and 1.0 $\mathrm{mg}$, respectively) and made up to final volume with ultrapurified water. The solutions contending final concentrations of $15.0,17.5$ and $20.0 \mu \mathrm{g} / \mathrm{mL}$ of cefpirome were submitted to the chromatographic assay described above. Each solution was prepared in triplicate and injected three times in two days.

\section{Specificity}

The specificity was determined by measurement in presence of degradation products. Commercially obtained samples were diluted in injectable water at a concentration of 100 $\mathrm{mg} / \mathrm{mL}$ of cefpirome were submitted to accelerated degradation at $40{ }^{\circ} \mathrm{C}$ for twenty four hours, in climatic 
chamber with controlled humidity Nova Ética 420 LDC (Nova Ética, São Paulo, Brazil), for thermal stress, and solutions contending $0.6 \mathrm{mg} / \mathrm{mL}$ of cefpirome, for photodegradation studies using UV light $(254 \mathrm{~nm})$ for one hour, respectively. These solutions were then diluted with $0.1 \mathrm{M}$ hydrochloric acid to obtain the theoretical concentration of $12 \mu \mathrm{g} / \mathrm{mL}$ for UV spectrophotometry method, and with ultra purifies water to obtain the theoretical concentration of $10 \mu \mathrm{g} / \mathrm{mL}$, for HPLC method, and were assayed against freshly prepared solution of reference standard and sample at the same concentrations. Each sample was analyzed six times. In the case of UV spectrophotometry method, was verificated the influence of others cephalosporins. In the case of the HPLC method, also was determined the peak purity.

\section{Detection limit}

The detection limit was calculated based on the standard deviation of the response and the slope. Both estimated from the calibration curve of the cefpirome (20).

\section{Quantitation limit}

The quantitation limit was calculated based on the standard deviation of the response and the slope. Both estimated from the calibration curve of the cefpirome (20).

\section{Robustness}

The evaluation of robustness was during the development phase and under study. In the case of UV spectrophotometry method, were studied the influence of concentration of solvent (0.08 and $0.12 \mathrm{M}$ hydrochloric acids) and different equipment. In the case of HPLC method, were studied the influence of variations in mobile phase composition (methanol-water 35:65, 25:75 and 20:80 v/v), different solvent, different flow rate $(0.7,1.0$ and $1.2 \mathrm{~mL} / \mathrm{min}$, different column and different equipment.

\section{Analytical solution stability}

The analytical solutions stability was determined by comparison of quantitation of components in solutions after storage conditions (depends on need) to freshly prepared standards. In this study, the solutions were kept at room temperature for 6 and 24 hours and stored refrigerated at 5 ${ }^{\circ} \mathrm{C}$ for 24 and 48 hours.

\section{Results and Discussion}

The validation of analytical procedures is an important part of the registration application for a new pharmaceutical preparation. Beyond the regulatory requirements, the performance and reliability of the control test procedure are essential to the quality control of drugs. Results which reflect the quality of the pharmaceutical to be tested may easily lead to drastic financial consequences. Therefore, validation should be regarded as part of an integrated concept to ensure the quality, safety and efficacy of pharmaceuticals $(23,24)$.

The elaboration of the methods described was begun by developing optimal conditions. Several conditions were investigated for each method and chosen optimal variants against common criteria critical in quantitative analysis, such as solvent, selectivity and linearity.
To choose the best wavelength and solvent to be used in UV spectrophotometry method, spectra were performed on UVVIS spectrophotometer using ultra purified water, $0.1 \mathrm{M}$ hydrochloric acid, ethanol and methanol. 0.1 M hydrochloric acid and the wavelength $271 \mathrm{~nm}$ were chosen the best experimental conditions (Figure 2).

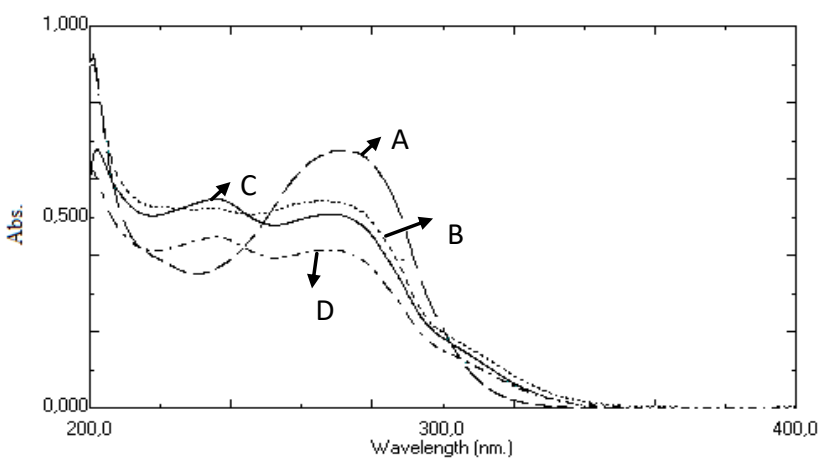

Figure 2. Absorption spectrum of cefpirome in different solvents (12 $\mu \mathrm{g} / \mathrm{mL}$ ): (A) $0.1 \mathrm{M}$ hydrochloric acid, (B) water; (C) methanol and (D) ethanol.

The linearity of an analytical method is its ability to elicit test results that are directly, or by a well-defined mathematical transformation, proportional to the concentration of analyte in samples within a given range (25).

Using the Ringbom's curve (Figure 3), the calibration curves were performed and the results showed good linearity on the range of concentration of cefpirome between 2.0 to $22.0 \mu \mathrm{g} / \mathrm{mL}$ for the UV spectrophotometry method (Figure 4). The calibration curves were constructed by plotting concentration versus absorbance and showed good linearity with excellent correlation coefficients $(r)$. The representative linear equation for cefpirome was $\mathrm{y}=0.0437 \mathrm{x}+0.0027(\mathrm{n}=$ $9, \mathrm{r}=0.9994)$. There are no deviation from parallelism and linearity with results obtained (Fcalculated $<$ Fcritical $\mathrm{p}=$ 0.01 ) as showed in Table 1.

Ringbom's curve of cefpirom in $0.1 \mathrm{M} \mathrm{HCl}$

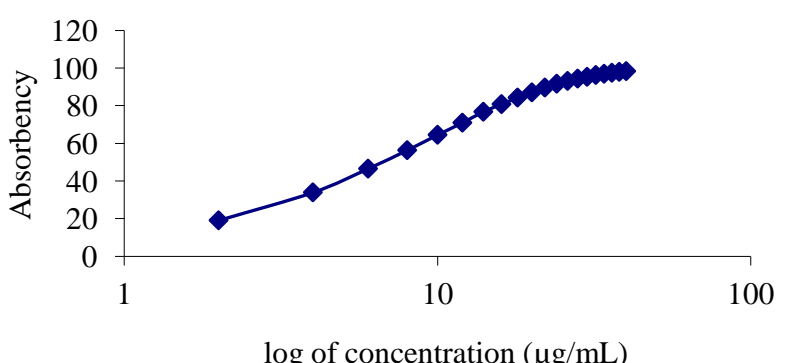

Figure 3. Ringbom plot. Standard curve for cefpirome (2.0 - 40.0 $\mu \mathrm{g} / \mathrm{mL}$, in $0.1 \mathrm{M}$ hydrochloric acid), by UV spectrophotometry at $271 \mathrm{~nm}$. 


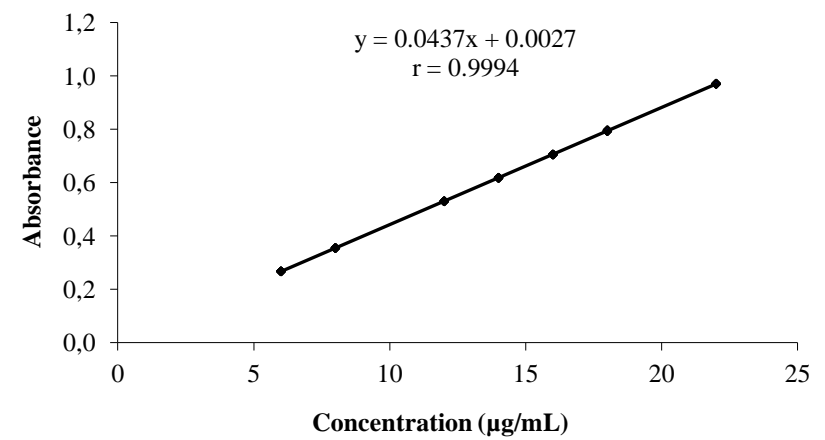

Figure 4. Calibration curve of cefpirome in $0.1 \mathrm{M}$ hydrochloric acid, by UV spectrophotometry at $271 \mathrm{~nm}$. The best fit line calculated by the method of least squares is shown.

Table 1. Analysis of variance of the data obtained from the UV Spectrophotometry method for determination of cefpirome.

\begin{tabular}{ccccc}
\hline $\begin{array}{c}\text { Source of } \\
\text { variation }\end{array}$ & $\begin{array}{c}\text { Degrees of } \\
\text { freedom }\end{array}$ & $\begin{array}{c}\text { Sum of } \\
\text { Squares }\end{array}$ & $\begin{array}{c}\text { Mean } \\
\text { squares }\end{array}$ & $\boldsymbol{F}$ \\
\hline Between & 6 & 2.169 & 0.361 & $4.41 \times 10^{51}$ \\
Regression & 1 & 2.169 & 2.169 & $2.65 \times 10^{61}$ \\
Deviation & 5 & $1.08 \times 10^{-5}$ & $2.16 \times 10^{-6}$ & 2.64 \\
Within & 35 & $2.87 \times 10^{-5}$ & $8.19 \times 10^{-7}$ & ----- \\
Total & 41 & 2.169 & ----- & ----- \\
\hline
\end{tabular}

${ }^{\mathrm{T}}$ Significant at $\mathrm{p}=0.01$

Each value is the mean of 6 assays.

For the development and validation of the method by HPLC, columns, solvents, different combinations and proportions of solvent, wavelength, flow, $\mathrm{pH}$ and temperatures were tested in order to obtain the best analytical conditions for quantification of cefpirome. The best system suitability was obtained when the Techsphere ${ }^{\circledR}$ ODS RP-18 column $(5 \mu \mathrm{m}$, $250 \mathrm{~mm} \times 4.6 \mathrm{~mm})$, methanol-water (30:70, v/v) as mobile phase, flow rate at $0.8 \mathrm{~mL} / \mathrm{min}$ and temperature at $25{ }^{\circ} \mathrm{C}$ were used. The retention time of cefpirome was about 6.9 min. as shown in Figure 5.

In this HPLC method, the calibration curves were constructed by plotting concentration versus peak area and showed good linearity, on the range concentration of cefpirome between 2.0 to $20.0 \mu \mathrm{g} / \mathrm{mL}$ (Figure 6), with excellent correlation coefficients $(r)$. The representative linear equation for cefpirome was $\mathrm{y}=4.6823 \mathrm{x}+0.4555(\mathrm{n}=$ $6, r=0.9996)$ There are no deviation from parallelism and linearity with results obtained (Fcalculated $\angle$ Fcritical $\mathrm{p}=$ 0.01 ) as showed in Table 2.

The detection limit (DL) is the lowest amount of analyte in a sample that can be detected, but not necessarily quantitated, under the stated experimental conditions. The quantitation limit (QL) is the lowest amount of analyte in a sample that can be determined with acceptable precision and accuracy under stated experimental conditions. The DL and QL are usually expressed as the concentration of analyte in the sample (19-22). Although some guidelines of validation on analytical procedures don't ask the calculation of DL and QL for the pharmaceutical product, these limits were determined in this study. In the case of the UV spectrophotometry method, the DL and QL were 0.19 and
$0.62 \mu \mathrm{g} / \mathrm{mL}$, respectably. In the case of HPLC method, the DL and QL were 0.09 and $0.27 \mu \mathrm{g} / \mathrm{mL}$ respectably. These results showed that the both methods were very sensible.

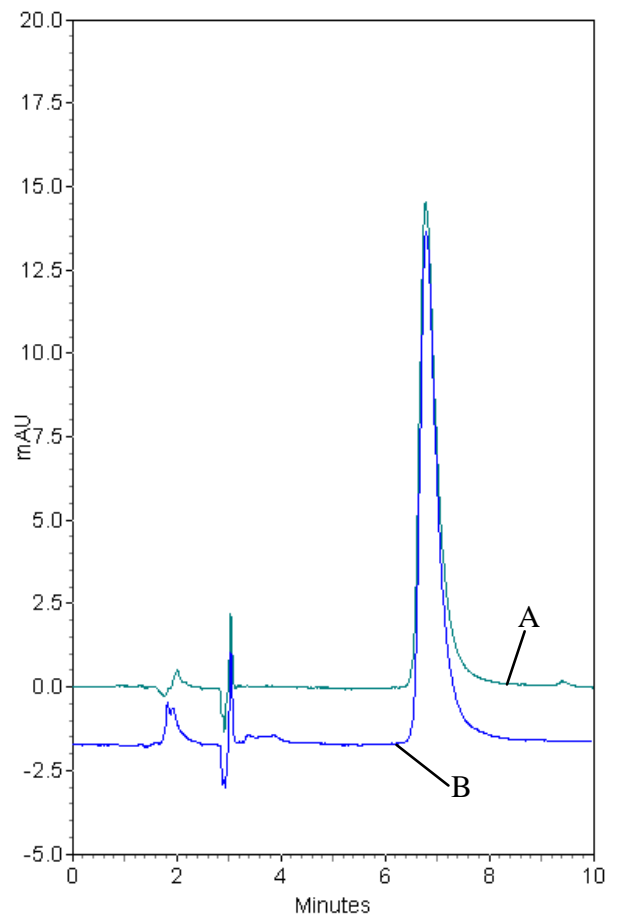

Figure 5. Chromatogram of cefpirome in ultra-purified water (12 $\mu \mathrm{g} / \mathrm{mL}$ ): (A) cefpirome standard, (B) cefpirome sample. Chromatographic conditions: Techsphere ${ }^{\circledR}$ ODS RP-18 column (5 $\mu \mathrm{m}, 250 \mathrm{~mm} \times 4.6 \mathrm{~mm})$, methanol-water (30:70, v/v) as mobile phase, flow rate at $0.8 \mathrm{~mL} / \mathrm{min}$ and temperature at $25^{\circ} \mathrm{C}$.

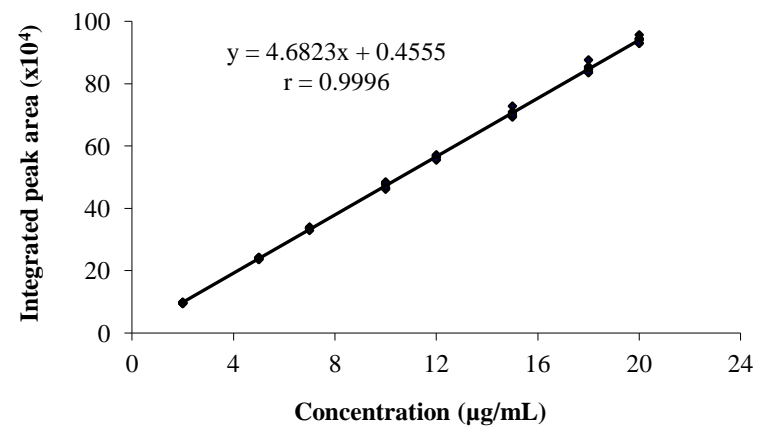

Figure 6. Calibration curve of cefpirome in water, by HPLC method at $265 \mathrm{~nm}$. The best fit line calculated by the method of least squares is shown.

Table 2. Analysis of variance of the data obtained from the HPLC method for determination of cefpirome.

\begin{tabular}{lcccc}
\hline $\begin{array}{l}\text { Source of } \\
\text { variation }\end{array}$ & $\begin{array}{c}\text { Degrees } \\
\text { of } \\
\text { freedom }\end{array}$ & $\begin{array}{c}\text { Sum of } \\
\text { Squares }\end{array}$ & $\begin{array}{c}\text { Mean } \\
\text { squares }\end{array}$ & F \\
\hline Between & 7 & 36949.38 & 5278.48 & $6610.28^{1}$ \\
Regression & 1 & 36947.19 & 36947.19 & $46269.23^{1}$ \\
Deviation & 6 & 2.19 & 0.37 & 0.46 \\
Within & 40 & 31.94 & 0.80 & ----- \\
Total & 47 & 36981.32 & ----- & ---- \\
\hline
\end{tabular}

${ }^{1}$ Significant at $p=0.01$

Each value is the mean of 6 assays. 
The precision of the assay was determined by repeatability and intermediate precision which results were expressed as the relative standard deviation (RSD) of a series of measurements in the same day and on different days respectively. The precision of an analytical method is the degree of agreement among individual test results when the method is applied repeatedly to multiple samplings of a homogeneous sample (20-23). The repeatability was studied by determination of the samples in six assays, at the same concentration, during the same day under the same experimental conditions. The result obtained shows RSD of 0.47 and 0.99 to UV spectrophotometry and HPLC method, respectively, indicating good intra-assay precision. Interassay variability was calculated from assays on 3 days and shows RSD of 0.80 and 1.24 to UV spectrophotometry and HPLC method, respectively (Tables 3 and 4).

Table 3. Results of the determination of cefpirome in powder for injection by UV Spectrophotometry method.

\begin{tabular}{|c|c|c|c|c|c|}
\hline $\begin{array}{c}\text { Sample } \\
\text { (mg) }\end{array}$ & $\begin{array}{c}\text { Experimental amount } \\
(\mathrm{mg})\end{array}$ & $\begin{array}{c}\begin{array}{c}\text { Concentration } \\
(\mathrm{mg} / \mathrm{g})^{1}\end{array} \\
\end{array}$ & $\begin{array}{c}\text { Mean of concentration } \\
(\mathrm{mg} / \mathrm{g})\end{array}$ & $\begin{array}{c}\text { RSD }(\%)^{2} \\
\text { Intra-assay }\end{array}$ & $\begin{array}{c}\text { RSD (\%) })^{2} \\
\text { Inter-assay }\end{array}$ \\
\hline 31.20 & 22.56 & 723.00 & & & \\
\hline 31.30 & 22.78 & 727.70 & & & \\
\hline 31.20 & 22.74 & 728.70 & 730.00 & 0.61 & \\
\hline 31.20 & 22.85 & 732.30 & & & \\
\hline 31.20 & 22.94 & 735.40 & & & \\
\hline 31.20 & 22.86 & 732.70 & & & \\
\hline 31.30 & 22.93 & 732.60 & & & \\
\hline 31.20 & 22.54 & 722.50 & & & \\
\hline 31.20 & 22.46 & 719.80 & 723.00 & 0.71 & \\
\hline 31.30 & 22.47 & 718.00 & & & 0.80 \\
\hline 31.20 & 22.50 & 721.20 & & & \\
\hline 31.20 & 22.58 & 723.80 & & & \\
\hline 31.30 & 22.49 & 718.60 & & & \\
\hline 31.20 & 22.37 & 716.90 & & & \\
\hline 31.20 & 22.40 & 717.80 & 720.70 & 0.47 & \\
\hline 31.30 & 22.61 & 722.20 & & & \\
\hline 31.20 & 22.62 & 725.00 & & & \\
\hline \multirow[t]{2}{*}{31.30} & 22.65 & 723.60 & & & \\
\hline & \multicolumn{2}{|c|}{ Mean of concentration } & 724.60 & & \\
\hline
\end{tabular}

${ }^{1}$ Mean of three determinations

${ }^{2}$ RSD (Relative standard deviation)

Table 4. Results of the determination of cefpirome in powder for injection by HPLC method.

\begin{tabular}{|c|c|c|c|c|c|}
\hline $\begin{array}{c}\text { Sample powder for } \\
\text { injectable } \\
(\mathrm{mg})\end{array}$ & $\begin{array}{l}\text { Experimental amount } \\
(\mathrm{mg})\end{array}$ & $\begin{array}{l}\text { Concentration } \\
(\mathrm{mg} / \mathrm{g})^{1}\end{array}$ & $\begin{array}{c}\text { Mean of concentration } \\
(\mathrm{mg} / \mathrm{g})\end{array}$ & $\begin{array}{l}\mathrm{RSD}(\%)^{2} \\
\text { Intra-assay }\end{array}$ & $\begin{array}{l}\operatorname{RSD}(\%)^{2} \\
\text { Inter-assay }\end{array}$ \\
\hline 40.00 & 28.62 & 715.53 & & & \\
\hline 40.10 & 28.26 & 704.82 & & & \\
\hline 40.20 & 28.34 & 704.96 & 712.48 & 1.04 & \\
\hline 40.20 & 28.50 & 708.96 & & & \\
\hline 40.10 & 28.78 & 717.67 & & & \\
\hline 40.10 & 28.99 & 722.92 & & & \\
\hline 40.00 & 28.43 & 710.83 & & & \\
\hline 40.10 & 29.30 & 730.73 & & & \\
\hline 40.50 & 29.54 & 729.41 & 724.64 & 0.99 & \\
\hline 40.50 & 29.35 & 724.63 & & & 1.24 \\
\hline 40.10 & 29.07 & 724.91 & & & \\
\hline 40.40 & 29.38 & 727.30 & & & \\
\hline 39.90 & 28.27 & 708.41 & & & \\
\hline 40.10 & 28.90 & 720.63 & & & \\
\hline 40.20 & 29.17 & 725.73 & 718.11 & 1.21 & \\
\hline 40.10 & 28.33 & 706.54 & & & \\
\hline 40.40 & 29.37 & 726.90 & & & \\
\hline \multirow[t]{2}{*}{40.00} & 28.82 & 720.45 & & & \\
\hline & Mean & tration & 718.41 & & \\
\hline
\end{tabular}

${ }^{1}$ Mean of four determinations

${ }^{2}$ RSD (Relative standard deviation) 
The accuracy was proved by recovery test that are experimental designs to determine the agreement between the values found of the analyte and the real value that analyses (20-23). The recovery test was performed with three different concentration was the mean recovery were found to be $98.41 \%$ of reference substance (UV spectrophotometry method) and $101.14 \%$ (HPLC method) (Tables 5 and 6).

Table 5. Experimental values obtained in the recovery test for cefpirome in powder for injection by UV spectrophotometry method.

\begin{tabular}{ccc}
\hline $\begin{array}{c}\text { Amount of } \\
\text { standard added } \\
(\mu \mathrm{g})\end{array}$ & $\begin{array}{c}\text { Amount of } \\
\text { standard found } \\
(\mu \mathrm{g})\end{array}$ & $\begin{array}{c}\text { Percentage recovery } \\
\operatorname{RSD}(\%)^{2}\end{array}$ \\
\hline 300.0 & 290.7 & $97.98 \pm 0.82$ \\
600.0 & 589.5 & $99.34 \pm 0.67$ \\
900.0 & 871.6 & $97.92 \pm 0.65$ \\
\hline
\end{tabular}

${ }^{1}$ Mean of six determinations.

${ }^{2}$ RSD (Relative standard deviation)

Table 6. Experimental values obtained in the recovery test for cefpirome in powder for injection by HPLC method.

\begin{tabular}{ccc}
\hline $\begin{array}{c}\text { Amount of } \\
\text { standard added } \\
(\mu \mathrm{g})\end{array}$ & $\begin{array}{c}\text { Amount of } \\
\text { standard found } \\
(\mu \mathrm{g})\end{array}$ & $\begin{array}{c}\text { Percentage recovery }{ }^{1} \pm \\
\operatorname{RSD}(\%)\end{array}$ \\
\hline 500.0 & 503.2 & $100.64 \pm 0.94$ \\
700.0 & 744.0 & $99.20 \pm 0.89$ \\
1000.0 & 1001.7 & $100.17 \pm 0.73$ \\
\hline${ }^{1}$ Mean of six determinations. & \\
${ }^{2}$ RSD (Relative standard deviation) &
\end{tabular}

Specificity is defined as the ability to assess unequivocally the analyte in the presence of components that may be expected to be present, such as impurities, degradation products and matrix components (14-17). The specificity of the proposed methods was studied analysis of degraded samples (Figures 7 and 8). In case of the HPLC method, also was verificated the peak purity. The results obtained demonstrate that a decrease occurred in the concentration of cefpirome under the conditions used. The results were expressed as a percentage of the drug remaining (Tables 7 and 8).

Cefpirome was very instable at $40{ }^{\circ} \mathrm{C}$ and exposed to UV light $(254 \mathrm{~nm})$. After the degradation treatment, the contents of the containers were diluted with the $0.1 \mathrm{M}$ hydrochloric acid or ultra-purified water, for UV spectrophotometry and HPLC methods, respectively, and showed loss of concentration (Figures 7 and 8).

The spectrophotometric and chromatographic assays described were specific for the determination of cefpirome in the presence of possible degradation products.

Figure 9 shows the purity curve obtained in the determination of cefpirome by the proposed chromatographic method in the analysis of the aqueous solution of the pharmaceutical form exposed to thermal degradation at $40{ }^{\circ} \mathrm{C}$ stored for two days. The high purity value indicates that the chromatographic method has specificity against the likely degradation products.

Table 7. Results of Specificity and Robustness tests and analytical solution stability, by UV spectrophotometry assay.

\begin{tabular}{|c|c|c|}
\hline Sample & $\begin{array}{l}\text { Mean absorbance, } \\
\operatorname{RSD}(\%)^{1}\end{array}$ & $\begin{array}{c}\text { Mean } \\
\text { concentration } \\
(\%) \\
\end{array}$ \\
\hline Standard in $0.1 \mathrm{M} \mathrm{HCl}$ & $0.570(0.13)$ & 100.00 \\
\hline Sample in $0.1 \mathrm{M} \mathrm{HCl}$ & $0.569(0.67)$ & 99.82 \\
\hline $\begin{array}{l}\text { Degradated sample stored } \\
\text { at } 40^{\circ} \mathrm{C} \text { for } 2 \text { days }\end{array}$ & $0.286(0.74)$ & 50.18 \\
\hline $\begin{array}{l}\text { Degradated sample }(0.6 \\
\mathrm{mg} / \mathrm{mL}) \text { stored at UV light } \\
(254 \mathrm{~nm}) \text { for } 1 \mathrm{~h}\end{array}$ & $0.278(0.55)$ & 48.72 \\
\hline $\begin{array}{l}\text { Standard solution stored at } \\
5^{\circ} \mathrm{C} \text { for } 24 \mathrm{~h}\end{array}$ & $0.570(0.39)$ & 100.18 \\
\hline $\begin{array}{l}\text { Standard solution stored at } \\
5^{\circ} \mathrm{C} \text { for } 48 \mathrm{~h}\end{array}$ & $0.569(0.82)$ & 99.74 \\
\hline $\begin{array}{l}\text { Sample solution stored at } \\
\text { room temperature for } 6 \mathrm{~h}\end{array}$ & $0.572(0.91)$ & 100.44 \\
\hline $\begin{array}{l}\text { Sample solution stored at } \\
\text { room temperature for } 24 \mathrm{~h}\end{array}$ & $0.567(1.58)$ & 99.57 \\
\hline Sample in $0.8 \mathrm{M} \mathrm{HCl}$ & $0.569(1.02)$ & 99.86 \\
\hline Sample in $1.2 \mathrm{M} \mathrm{HCl}$ & $0.567(0.86)$ & 99.51 \\
\hline Equipment $2^{2}$ & $0.565(0.54)$ & $99.19^{3}$ \\
\hline \multicolumn{3}{|c|}{$\begin{array}{l}{ }^{1} \text { Mean of six determinations, RSD (Relative standard deviation). } \\
2 \text { Equipment 2: Spectrophotometer SHIMADZU UV - 160A } \\
\text { (Shimadzu, Kyoto, Japan). } \\
{ }^{3} \text { Statistic analyze by Student's } t \text {-test demonstrated no significant } \\
\text { difference between the two spectrophotometer ( } \mathrm{p}=0.01 \text { ). }\end{array}$} \\
\hline
\end{tabular}

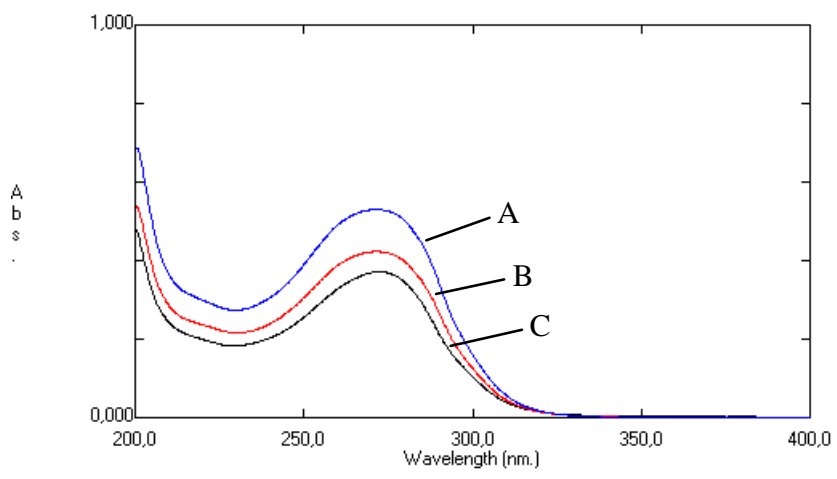

Figure 7. Absorption spectra of cefpirome in $0.1 \mathrm{M}$ hydrochloric acid $(12 \mu \mathrm{g} / \mathrm{mL})$ : (A) aqueous solution of cefpirome standard, degraded sample stored solution at $40{ }^{\circ} \mathrm{C}$ for $24 \mathrm{~h}(\mathrm{~B})$, degraded sample aqueous solution stored at UV light $(254 \mathrm{~nm})$ for $1 \mathrm{~h}$ and (C) . 
Table 8. Results of Specificity and Robustness tests and analytical solution stability, by HPLC method.

\begin{tabular}{|c|c|c|}
\hline Sample & $\begin{array}{c}\text { Mean Integrated } \\
\text { peak area, RSD } \\
(\%)^{1} \\
\end{array}$ & $\begin{array}{c}\text { Mean } \\
\text { concentration } \\
(\%) \\
\end{array}$ \\
\hline Standard & $468076.1(0.23)$ & 100.00 \\
\hline Sample & $469012,3(0.21)$ & 100.20 \\
\hline $\begin{array}{l}\text { Degradated sample stored } \\
\text { at } 40^{\circ} \mathrm{C} \text { for } 2 \text { days }\end{array}$ & $233804.0(0.62)$ & 49.95 \\
\hline $\begin{array}{l}\text { Degradated sample }(0.6 \\
\mathrm{mg} / \mathrm{mL}) \text { stored at UV light } \\
(254 \mathrm{~nm}) \text { for } 1 \mathrm{~h}\end{array}$ & $227531.8(0.46)$ & 48.61 \\
\hline $\begin{array}{l}\text { Standard solution stored at } \\
5^{\circ} \mathrm{C} \text { for } 24 \mathrm{~h}\end{array}$ & $468450.6(0.20)$ & 100.08 \\
\hline $\begin{array}{l}\text { Standard solution stored at } \\
5^{\circ} \mathrm{C} \text { for } 48 \mathrm{~h}\end{array}$ & $467888.9(0.18)$ & 99.96 \\
\hline $\begin{array}{l}\text { Sample solution stored at } \\
\text { room temperature for } 6 \mathrm{~h}\end{array}$ & $467701.6(0.33)$ & 99.92 \\
\hline $\begin{array}{l}\text { Sample solution stored at } \\
\text { room temperature for } 24 \mathrm{~h}\end{array}$ & $468450.6(0.13)$ & 100.08 \\
\hline Flow rate $0.7 \mathrm{~mL} / \mathrm{min}$ & $467514.4(0.18)$ & $99.88^{5}$ \\
\hline Flow rate $1.0 \mathrm{~mL} / \mathrm{min}$ & $463816.6(0.97)$ & $99.09^{5}$ \\
\hline Flow rate $1.2 \mathrm{~mL} / \mathrm{min}$ & $466484.6(0.66)$ & $99.66^{5}$ \\
\hline $\begin{array}{l}\text { Mobile phase methanol- } \\
\text { water }(35: 65 \mathrm{v} / \mathrm{v})\end{array}$ & $468403.7(0.99)$ & $100.07^{5}$ \\
\hline $\begin{array}{l}\text { Mobile phase methanol- } \\
\text { water }(25: 75 \mathrm{v} / \mathrm{v})\end{array}$ & $467982.5(0.78)$ & $99.98^{5}$ \\
\hline $\begin{array}{l}\text { Mobile phase methanol- } \\
\text { water }(20: 80 \mathrm{v} / \mathrm{v})\end{array}$ & $464003.8(0.55)$ & $99.13^{5}$ \\
\hline Equipment $2^{2}$ & $468169.7(0.33)$ & $100.02^{5}$ \\
\hline Column $2^{3}$ & $466812.3(0.51)$ & $99.73^{5}$ \\
\hline Solvent $2^{4}$ & $467327.2(0.22)$ & $99.84^{5}$ \\
\hline \multicolumn{3}{|c|}{$\begin{array}{l}{ }^{1} \text { Mean of six determinations, RSD (Relative standard deviation). } \\
{ }^{2} \text { Chromatographer Schimadzu LC-10A, with SPD-10A variable- } \\
\text { wavelength detector (set at } 265 \mathrm{~nm} \text { ), an SCL-10A system } \\
\text { controller, a LC } 10 \mathrm{AS} \text { pump, a C-R6A integrator and Rheodyne } \\
\text { injection valve with } 20 \mu \mathrm{L} \text { loop (Shimadzu, Kyoto, Japan) } \\
{ }^{3} \text { ACE HPLC Column C18 (5 } \mu, 250 \mathrm{~mm} \text { x } 4 \mathrm{~mm} \text { ) (Nova } \\
\text { Analitica, São Paulo, Brazil) } \\
{ }^{4} \text { Methanol Tedia (Tedia Brazil, Rio de Janeiro, Brazil) } \\
{ }^{5} \text { Statistic analyze by Student's } t \text {-test demonstrated no significant } \\
\text { difference between the two parameters }(\mathrm{p}=0.01 \text { ), }\end{array}$} \\
\hline
\end{tabular}

Robustness is defined as a measure of capability of the method to remain unaffected by small, but deliberate variations in method parameters. The Tables 7 and 8 shows that the solutions assayed in robustness test exhibited no concentration changes of cefpirome.

To generate reproducible and reliable results, the stability of sample solution, standards and reagents must be determined prior to initiating the method validation studies. It is often essential that solutions be stable enough to allow for delays. Samples and standards should be tested over a time period and quantitation of components should be determined by comparison to freshly prepared standards. A stability criterion for assay methods is that sample and standard solutions be stable for under defined storage conditions. Acceptable stability is $2 \%$ change in standard or sample response, relative to freshly prepared standards (23).

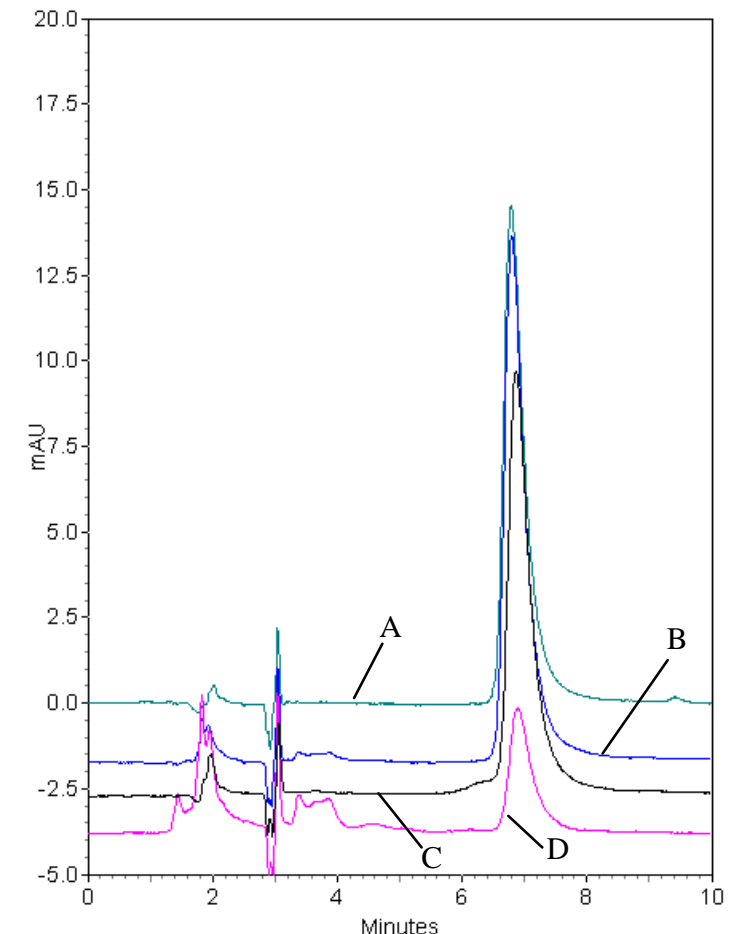

Figure 8. Chromatogram of cefpirome in ultra-purified water (10 $\mu \mathrm{g} / \mathrm{mL}$ ): (A) cefpirome reference substance, (B) cefpirome sample, (C) degraded sample solution stored at UV light $(254 \mathrm{~nm})$ for $1 \mathrm{~h}$ and (D) degraded sample stored solution at $40{ }^{\circ} \mathrm{C}$ for $24 \mathrm{~h}$.

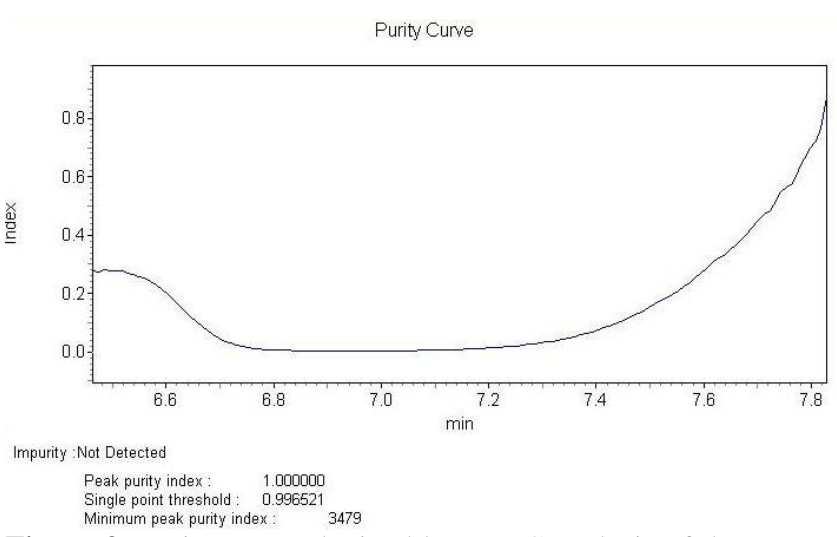

Figure 9. Purity curve obtained by HPLC analysis of the aqueous solution of cefpirome (pharmaceutical form) exposed to thermal degradation at $40{ }^{\circ} \mathrm{C}$ for two days.

The analytical solutions of cefpirome in $0.1 \mathrm{M}$ hydrochloric acid $(240 \mu \mathrm{g} / \mathrm{mL})$ and water (reference - $250 \mu \mathrm{g} / \mathrm{mL})$, kept at refrigerated temperature $\left(5^{\circ} \mathrm{C}\right)$ and room temperature for 24 and 48 hours, exhibited no concentration changes of cefpirome changes (Tables 7 and 8).

The methods were compared by Student's t-test and no significant difference between UV spectrophotometry and HPLC was observed ( $\mathrm{p}=0.01)$.

The results obtained in these assays were very satisfactory. Performed validation proved that UV spectrophotometry and Liquid Chromatography are good methods for pharmaceutical analysis of cefpirome in raw material and powder for injection. 


\section{Conclusions}

The results indicated that the UV spectrophotometric and chromatographic assay hold linearity, precision, accuracy, specificity and robustness at concentration range from 6 to $22 \mathrm{mg} / \mathrm{mL}$, UV spectrophotometry method, and from 2 to 20 $\mathrm{mg} / \mathrm{mL}$, HPLC method, being acceptable methods for the routine quality control of cefpirome in raw material and pharmaceutical preparation.

\section{Acknowledgments}

The authors are grateful to Aventis Pharma (Frankfurt, Germany) for providing the cefpirome reference standard, CNPq (Brasília, Brazil) and LCQFar (Porto Alegre, Brasil) by financial support.

\section{Conflict of interest}

The authors declare no conflicts of interest

\section{References}

1. Martínez LG, Falcó PC, Cabeza AS. Comparison of several methods used for the determination of cephalosporins. Analysis of cephalexin in pharmaceutical samples. J Pharm Biomed Anal. 2002; $305-423$.

2. Tumah H. Fourth-generation cephalosporins: in vitro activity against nosocomial gram-negative bacilli compared with beta-lactam antibiotics and ciprofloxacin. Chemotherapy. 2005; 51:80-85.

3. Lima B, Bodeau S, Quinton MC, Leven C, LemaireHurtel AS, Bennis Y. Validation and Application of an HPLC-DAD Method for Routine Therapeutic Drug Monitoring of Ceftobiprole. Antimicrobial Agents and Chemotherapy [serial online] 2019 July; 63(7):[6 screens]. Available from: URL:https://aac.asm.org/content/63/7/e00515-19.

4. The Merck Index 15th Ed., Royal Society of Chemistry: Cambridge; 2013.

5. Wiseman LR, Lamb HM. Cefpirome. A Review of its Antibacterial Activity, Pharmacokinetic Properties and Clinical Efficacy in the Treatment of Severe Nosocomial Infections and Febrile Neutropenia. Drugs. 1997; 54:117-140.

6. Tumah, HN. In vitro activity of cefepime and cefpirome compared to other third-generation cephem antibiotics against gram-negative nosocomial pathogens. Pharmazie. 2004; 59: 854-858.

7. Roos JF, Lipma J, Kirkpatrick CM. Population pharmacokinetics and pharmacodynamics of cefpirome in critically ill patients against Gram-negative bacteria. Intensive Care Med. 2007; 7:781-788.
8. Hollenstein U, Brumnner M, Mayer B, Delacher S, Erovic B, Eichler HG, et al. Target site concentrations after continuous infusion and bolus injection of cefpirome to healthy volunteers. Clinical Pharmacology \& Therapeutics. 2000; 67: 229-236.

9. Joukhadar C, Klein N, Mayer BX, Kreischitz N, DelleKarth G, Palkovits $P$, et al. Plasma and tissue pharmacokinetics of cefpirome in patients with sepsis. Critical Care Medicine. 2002, 30:1478-1482.

10. Mlynarczyk G, Mlynarczyk A, Bilewska A, Dukaczewska A, Golawski C, Kicman A, et al. High effectiveness of the method with cefpirome in detection of extended-spectrum beta-lactamases in different species of gram-negative bacilli. Medycyna Doswiadczalna I Mikrobiologia. 2006; 58:59-65.

11. Mrestani Y, Hartl A, Neubert RH. Influence of absorption enhancers on the pharmacokinetic properties of non-oral beta-lactam-cefpirom using the rabbit (Chinchilla) in vivo model. International Journal of Phamaceutics. 2006; 309:67-70.

12. Rajput N, Dumka VK, Sandhu HS. Disposition kinetics and urinary excretion of cefpirome after intravenous injection in buffalo calves. J Vet Scien. 2007; 8:21-25.

13. Nikolovski M, Kotsev IU, Panchev P, Treatment with cefrom (cefpirom) in severe urological infections. Khirurgiia (Sofiia). 2004; 60:39-41.

14. Oppe TP, Menegola J. Schapoval EES. Microbiological assay for the determination of cefpirome in raw material and injectable preparation. Drug analytical research. 2018, 2:29-35.

15. Zalewski P, Skibiński R, Cielecka-Piontek J, BednarekRajewska K. Development and validation of stabilityindicating HPLC method for determination of cefpirome sulfate. Acta Pol Pharm. 2014; 71:731-736.

16. Vikas JR. Voltammetric determination of cefpirome at multiwalled carbon nanotube modified glassy carbon sensor based electrode in bulk form and pharmaceutical formulation. Colloids Surf B Biointerfaces. 2011; $87: 423-426$.

17. Sriwiriyajan S, Mahatthanatrakul W. Development of an analytical method for cefpirome in plasma by simplified HPLC technique and its applications. Arzneimittelforschung. 2010; 60:336-933.

18. Arayne MS, Sultana N, Nawaz M. A rp-HPLC method for the assay of cefpirome and its application in drugmetal interaction studies. Pak J Pharm Sci. 2006 ;19:3944.

19. Evagelou V, Tsantili-Kaloulidou A, Koupparis M, Determination of the Dissociation Constants of the 
Cephalosporins Cefepime and Cefpirome using UV Spectrometry and $\mathrm{pH}$ Potentiometry. J Pharm Biomed Anal. 2003; 31:1119-1128.

20. International Conference on Harmonization (ICH), Validation of Analytical Procedures: Text and Methodology, Q2 (R1), 2005.

21. The United States Pharmacopeia 42th ed. Rochville: United States Pharmacopoeial Convention, 2019.

22. AOAC, Official Methods of Analytical Chemists of AOAC, 15th ed. XVII, 1990.

23. Ermer, J. Validation in Pharmaceutical Analysis. Part I: An Integrated Approach. Journal of Pharmaceutical and Biomedical Analysis, v. 24, p. 755-767, 2001.

24. Leito S, Mölder K, Künnapas A, Herodes K, Leito I. Uncertainty in liquid chromatographic analysis of pharmaceutical product: Influence of various uncertainty sources. J. Chromatogr. A. 2006; 1121:55-63.

25. Rauber C.S, Guterres SS, Schapoval EES. LC determination of citral in Cymbopogon citratus volatile oil. J. Pharm. Biomed. Anal. 2005; 37:597-601.

26. Costa MCN, Barden AT, Andrade JMM, Oppe TP, Schapoval EES. Quantitative evaluation of besifloxacin ophthalmic suspension by HPLC, application to bioassay method and cytotoxicity studies. Talanta.119:367-374. 